\title{
Tubular Antigen-binding Proteins Repress Transcription of Type IV Collagen in the Autoimmune Target Epithelium of Experimental Interstitial Nephritis
}

\author{
Thomas P. Haverty, Carolyn J. Kelly, John R. Hoyer, Rene Alvarez, and Eric G. Neilson \\ Renal-Electrolyte Division of the Department of Medicine, the Department of Pediatrics, and the Cell Biology and Immunology \\ Graduate Groups, University of Pennsylvania School of Medicine, Philadelphia, Pennsylvania 19104-6144
}

\begin{abstract}
We have been studying immune interactions with somatic cells using a tubular antigen-binding protein (ThF) secreted by helper $T$ lymphocytes harvested from mice that have an autoimmune form of interstitial nephritis called anti-tubular basement membrane disease. This ThF, although characterized originally because of its ability to induce effector $T$ cells, additionally recognizes the nephritogenic $3 \mathrm{M}-1$ antigen expressed by its target renal tubular epithelium. We believe these proteins, in general, may modulate directly some homeostatic functions in organ-derived cells, and now report that our $\mathrm{ThF}$ represses specifically the cellular transcription and secretion of basement membrane type IV collagen in tubular epithelium. These in vitro findings of reduced levels of mRNA encoding type IV collagen correlate well with in situ hybridization studies performed on kidneys expressing early autoimmune lesions, and predict a progressive drop in the expression of type IV collagen in the interstitium. Such a novel and unexpected repression of transcription of type IV collagen might easily impart or facilitate permanent change in the infrastructure of kidney architecture during autoimmune injury and, perhaps, contributes to the process of tubular atrophy attendant to prolonged renal inflammation. (J. Clin. Invest. 1992. 89:517-523.) Key words: renal epithelium • basement membranes $\cdot T$ cells $\bullet$ autoimmune tubular atrophy
\end{abstract}

\section{Introduction}

Approximately 10 years ago we observed that crude culture supernatants from immune lymphocytes in autoimmune interstitial nephritis could alter the biology of kidney cells in vitro $(1,2)$. These early experiments suggested the possibility of interactions between immune and somatic cells. Since that time we have been able to both characterize the relevant nephritogenic $3 \mathrm{M}-1$ target antigen $(3,4)$ as well as establish $3 \mathrm{M}$-1-specific $\mathrm{CD}^{+}$helper $\mathrm{T}$ cell clones (5). These helper $\mathrm{T}$ cells are present within inflammatory tubulointerstitial infiltrates (5), secrete a 3M-1-binding protein $(\mathrm{ThF})^{1}$ of $\sim 78,000 M_{\mathrm{r}}(6)$, and

Address correspondence to Eric G. Neilson, M.D., Chief, Renal-Electrolyte Division, 700 Clinical Research Building, University of Pennsylvania, 422 Curie Boulevard, Philadelphia, PA 19104-6144.

Received for publication 26 March 1991 and in revised form 14 August 1991

1. Abbreviations used in this paper: EGF, epidermal growth factor; MCT, proximal tubular epithelium; RTA, renal tubular antigen; ThF, tubular antigen-ginding protein; TGF $\beta$, transforming growth factor $\beta$.

J. Clin. Invest.

(c) The American Society for Clinical Investigation, Inc.

$0021-9738 / 92 / 02 / 0517 / 07 \$ 2.00$

Volume 89, February 1992, 517-523 recognize $3 \mathrm{M}-1$ on the surface of cultured proximal tubular epithelium (MCT cells; 7, 8) from the kidney. In the presence of 3M-1 antigen, precursor cells, and IL-2, ThF can induce $\mathrm{CD}^{+}$effector $\mathrm{T}$ cells that produce nephritogenic injury $(6,9)$.

Cortical epithelium similar to our MCT cells rests normally in situ on a traditional basement membrane that, for the most part, is composed of type IV collagen (10-12). These cells and their basement membrane form elongated tubules which are held together by a scaffolding of types I and III interstitial fibrillar collagens (10). MCT cells in culture secrete measurable amounts of basement membrane type IV collagen, as well as lesser amounts of interstitial types I and III collagens (7). Since much of the cortical tubular architecture of the kidney undergoes destructive remodelling during autoimmune interstitial inflammation $(13,14)$, and since our $\mathrm{ThF}$ recognizes an autoantigen distributed only along cortical tubules $(3,4)$, we attempted in this report to determine what biologic effect ThF might have on the transcription and secretion of types I and IV collagens by MCT epithelium in culture.

\section{Methods}

Cell culture and preparation of antigen-binding protein. MCT cells from the kidneys of SJL mice were passaged in serum-free media supplemented with transferrin $(5 \mu \mathrm{g} / \mathrm{ml})$, insulin $(5 \mu \mathrm{g} / \mathrm{ml})$ at $37^{\circ} \mathrm{C}$ in $5 \%$ $\mathrm{CO}_{2}$ every 48-72 $\mathrm{h}(7)$. ThF was prepared from the cultures of $\mathrm{CD}^{+}$ M-30 (3M-1-specific) or M-12 (PPD-specific) helper T cell clones by immunoaffinity chromatography using a reverse-elution column (Pharamacia LKB Biotechnology Inc., Piscataway, NJ) containing solubilized tubular antigen $(1 \mathrm{mg} / \mathrm{ml})$ linked to Sepharose 4B $(6,9)$. Purifications were verified by the iodination of aliquots of each preparation of M30 ThF followed by resolution on $8 \%$ SDS-PAGE gels and autoradiography $(4,7)$.

Collagen radioimmunoassays. Serum-free cultures of $10^{4}$ near-confluent MCT cells (7), in flat-bottomed microtiter plates, were grown in serum-free media supplemented with transferrin $(5 \mu \mathrm{g} / \mathrm{ml})$, insulin $(5$ $\mu \mathrm{g} / \mathrm{ml})$, ascorbic acid $(50 \mu \mathrm{g} / \mathrm{ml})$, and $\beta$-aminoproprionitrile $(50 \mu \mathrm{g} /$ $\mathrm{ml}$ ), containing $50 \mu \mathrm{g} / \mathrm{ml}$ of ultrapure BSA, and various concentrations of ThF. M12-ThF and M30-ThF were secreted originally into a known volume of $\mathrm{T}$ cell culture media in cultures starting with $5 \times 10^{5} \mathrm{CD}^{+} \mathrm{T}$ cells $/ \mathrm{ml}$. These ThFs, after affinity purification, were restored to that original volume, and this volume was considered to contain or be equivalent to $100 \%$ of the original concentration. If the ThF were added to MCT cultures, for example, at $50 \%$ concentration, it would mean it had been added at $50 \%$ of its original secreted concentration. The BSA concentration, far in excess of the ThF, served to stabilize protein content. After $72 \mathrm{~h}$ of culture, the supernatants were harvested and assayed for types I or IV procollagens by radioimmunoassay, and cell growth was assessed by $\left[{ }^{3} \mathrm{H}\right] \mathrm{TdR}$ incorporation (7). Absolute amounts of measured collagen were normalized for cell growth detected by simultaneous thymidine incorporation. Replicate measurements were within 7\% SEM.

RNA analyses. Total RNA from near-confluent MCCT cells $(20 \mu \mathrm{g})$ was electrophoresed through a $1.2 \%$ agarose-formaldehyde gel and transferred to Zetabind (Cuno, Meriden, CT) for Northern hybridizations $(4,15)$. Hybridizations were performed at $62^{\circ} \mathrm{C}$ in $7 \%$ SDS, $0.5 \mathrm{M}$ 


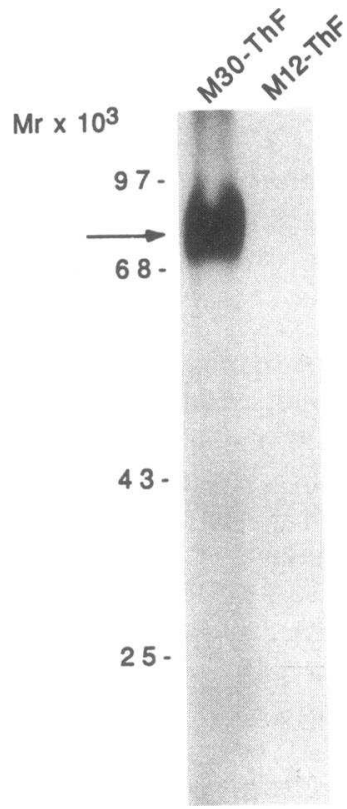

Figure 1. Visualization of ThF eluted from a soluble renal tubular antigen affinity column. Protein lysates harvested from M-30 T cells were passaged over a tubular antigen affinity column. Part of the eluate was then iodinated and electrophoresed on an $8 \%$ SDS-PAGE gel under reducing conditions to produce a band at $\sim 78,000 M_{\mathrm{r}}$ (arrow; 6). No such band was observed with protein lysates prepared from $\mathrm{M} 12$ cells reactive with purified protein derivative.

sodium hydrogen phosphate, $1 \mathrm{mM}$ EDTA, and $50 \mu \mathrm{g} / \mathrm{ml}$ polyadenylic acid with $50 \mu \mathrm{g} / \mathrm{ml}$ salmon sperm. Filters were washed at $65^{\circ} \mathrm{C}$ in $0.1 \%$ standard saline citrate (SSC) with $0.5 \%$ SDS, and exposed to Kodak XAR film at $-70^{\circ} \mathrm{C}$. Dot-blot hybridizations were performed in duplicate with cytoplasmic RNA harvested from $10^{6}$ MCT cells cultured with $\mathrm{ThF}$ using $0.1 \%$ trypsin in $1 \mathrm{mM}$ EDTA (15). The cells were washed in PBS, and lysed with $0.05 \%$ NP-40 in Tris-EDTA buffer.
Cytoplasmic RNA equivalent to $2 \times 10^{5}$ cells was denatured in $12 \times$ $\mathrm{SSC} / 15 \%$ formalin at $65^{\circ} \mathrm{C}$ and spotted onto Nytran (Gibco Laboratories, Grand Island, NY) by using a Hybridot manifold (Bethesda Research Laboratories, Gaithersburg, MD). The Northern and dot-blot filters were probed with ${ }^{32} \mathrm{P}$-labeled cDNAs $\left(\left[\mathrm{SA}=0.5-1.0 \times 10^{9} \mathrm{cpm} /\right.\right.$ $\mu \mathrm{g}]$ representing either a $0.85-\mathrm{kb}$ Xhol fragment of murine type $\alpha 2[\mathrm{I}]$ collagen from pAZ1002 [16], a 0.66-kb Pstl fragment of murine type $\alpha 1$ [IV] collagen from pc15 [17], or a $1.2 \mathrm{~kb}$-Pstl fragment of murine beta-actin from pAL41 [18]) in hybridization fluid comprised of $50 \%$ formamide, $2 \times$ Denhardt's solution, $150 \mu \mathrm{g} / \mathrm{ml} \mathrm{ssDNA}, 0.1 \%$ SDS, and $5 \times \mathrm{SSC}$ incubated at $42^{\circ} \mathrm{C}$ for $16 \mathrm{~h}$. The filters were washed $15 \mathrm{~min}$ twice in $6 \times \mathrm{SSC}, 0.5 \%$ SDS at $22^{\circ} \mathrm{C}$, and once in $0.1 \times \mathrm{SSC}, 0.5 \%$ SDS at $65^{\circ} \mathrm{C}$ for $1 \mathrm{~h}$, and then autoradiographed with intensifying screens at $-70^{\circ} \mathrm{C}$. Hybridization signals were quantitated using a densitometer of integration of signals by triangulation. Exposures were within the linear range of the film.

Transcriptional run-off assays. The in vitro transcription assay was performed on $10^{7}$ nuclei harvested from near-confluent monolayer cultures of MCT cells washed in PBS, released with trypsin, pelleted, and resuspended in $1 \mathrm{ml}$ of $0.5 \% \mathrm{NP}-40,10 \mathrm{mM}$ Tris (pH 7.0), $10 \mathrm{mM}$ $\mathrm{NaCl}, 3 \mathrm{mM} \mathrm{MgCl}$ for $5 \mathrm{~min}$ on ice (15). The samples were spun again and washed in $2 \mathrm{ml}$ of NP-40 buffer. Nuclear pellets were suspended in $100 \mu \mathrm{l}$ of $50 \mathrm{mM}$ Tris (pH 8.3), $40 \%$ glycerol, $5 \mathrm{mM} \mathrm{MgCl}_{2}$, and 0.1 mM EDTA and kept frozen. For labelling, nuclei were thawed and mixed with $100 \mu \mathrm{l}$ of $10 \mathrm{mM}$ Tris (pH 8.0), $5 \mathrm{mM} \mathrm{MgCl}_{2}, 300 \mathrm{mM}$ $\mathrm{KCl}, 0.5 \mathrm{mM}$ each of ATP, GTP, CTP, and $100 \mu \mathrm{l}$ of $\left[{ }^{32} \mathrm{P}\right] \mathrm{UTP}(>600$ $\mathrm{Ci} / \mathrm{mmol}$ ) for $30 \mathrm{~min}$ at $26^{\circ} \mathrm{C}$. Reactions were terminated on ice. An aliquot of $10 \mu \mathrm{l}$ of $10 \mathrm{mg} / \mathrm{ml} \mathrm{tRNA}$ was added, and nuclei were digested with $0.5 \mathrm{mg} / \mathrm{ml}$ DNAse I. Nuclear proteins were digested with $5 \mathrm{mg} / \mathrm{ml}$ of proteinase $\mathrm{K}$, followed by chloroform:phenol extraction and ethanol precipitation. Hybridization filters were prepared by linearizing and
A

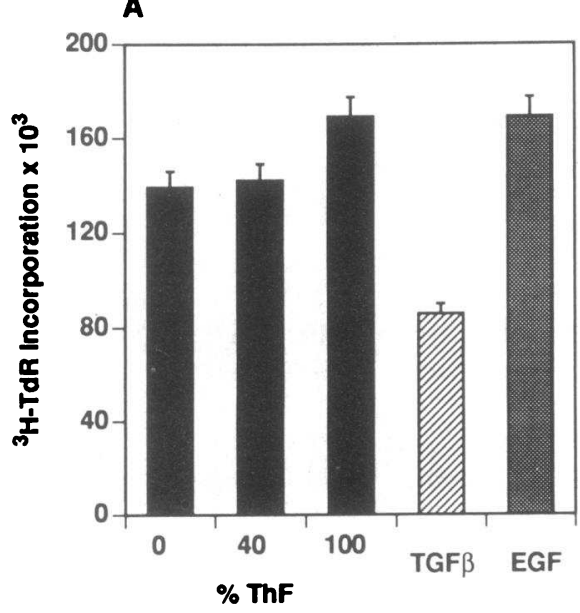

B

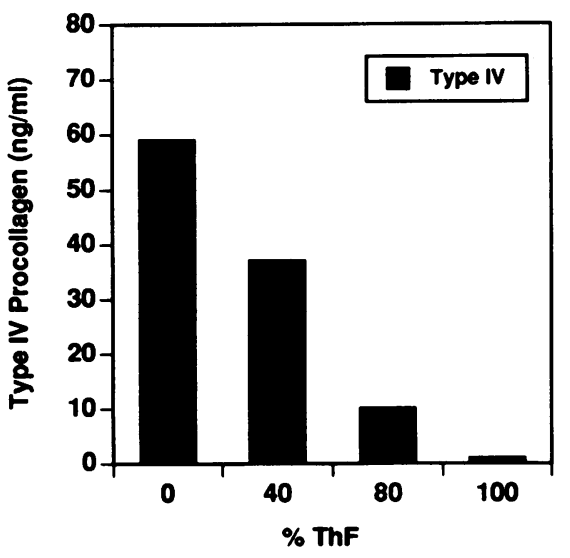

C

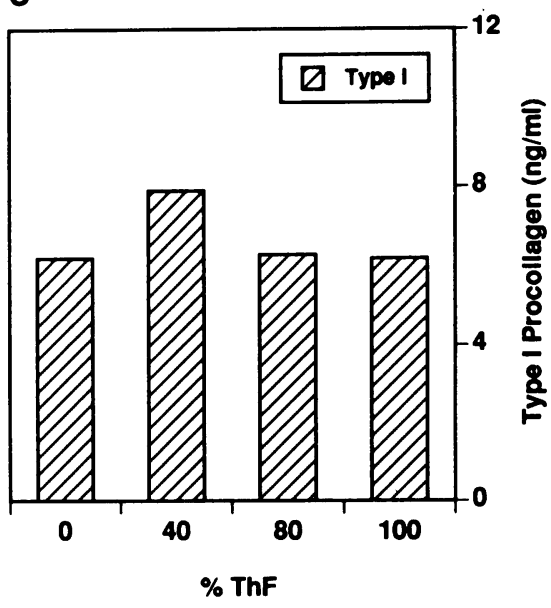

D

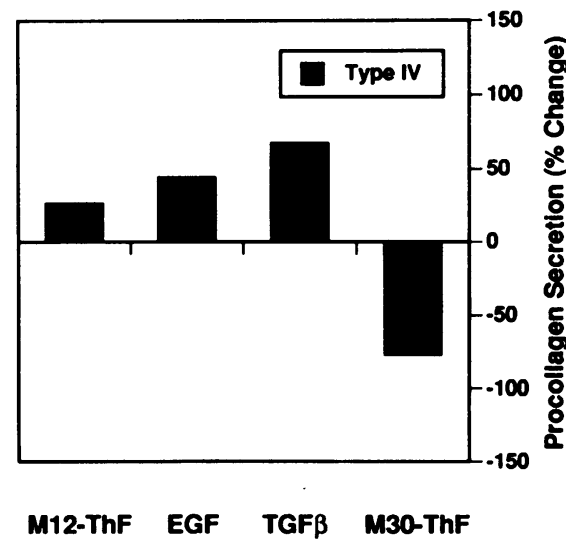

Figure 2. The effects of tubular antigen-binding proteins on collagen secretion by MCT epithelium (15). Experiments were performed multiple times with SEM for each assay varying only by $5-7 \%$. $(A)$ The addition of increasing amounts of $\mathrm{M} 30-\mathrm{ThF}$ to cultures of 3M-1-secreting MCT epithelium slightly increased the incorporation of $\left[{ }^{3} \mathrm{H}\right] \mathrm{TdR}$ at $72 \mathrm{~h}$. TGF $\beta$ at $1 \mathrm{ng} / \mathrm{ml}$ reduced MCT growth while EGF at $10 \mathrm{ng} / \mathrm{ml}$ increased it slightly; $(B)$ the addition of increasing amounts of M30-ThF to cultures of 3M-1-secreting MCT epithelium progressively inhibited the secretion of type IV collagen as measured by radioimmunoassay; (C) the same ThF had little to no effect on type I secretion, except to increase secretion slightly at mid-level doses. (D) M30-ThF inhibits the secretion of type IV collagen at $100 \%$ equivalent concentration, while ThF harvested from purified protein derivativereactive M12 T cells (M12-ThF; also at $100 \%$ equivalent concentration), TGF $\beta(1 \mathrm{ng} / \mathrm{ml})$, and $\operatorname{EGF}(10 \mathrm{ng} / \mathrm{ml})$ produced increases in collagen secretion. 


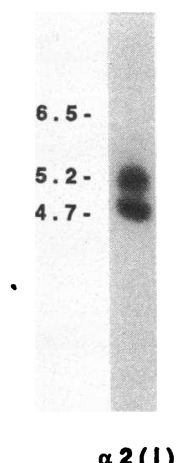

$\alpha 2(1)$

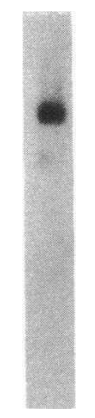

$\alpha 1$ (IV)
Figure 3. Northern hybridization of MCT RNA with ${ }^{32}$ P-labelled probes encoding for $\alpha 1$ (IV) and $\alpha 2$ (I) genes. Hybridizations revealed the presence of a 6.5 -kb transcript for $\alpha 1$ (IV), and 4.8 plus $5.8-\mathrm{kb}$ transcript for $\alpha 2(\mathrm{I})$ in MCT cells (19). denaturing various test plasmids, spotting 2- $\mu$ g equivalents of insert DNA onto nitrocellulose, and prehybridizing in $40 \%$ formamide, $4 \times$ SSC, $70 \mathrm{mM}$ Tris (pH 7.5), $1 \times$ Denhardt's solution, $0.4 \%$ SDS, $5 \mathrm{mM}$ EDTA, $150 \mu \mathrm{g} / \mathrm{ml} \mathrm{ssDNA}$ containing $60 \mathrm{mg} / \mathrm{ml}$ each of poly(A) and poly $(\mathrm{C})$ for $72 \mathrm{~h}$ at $42^{\circ} \mathrm{C}$. Fresh hybridization fluid was added with 2-3 $\times 10^{5} \mathrm{cpm}{ }^{32} \mathrm{P}$-labelled RNA, and hybridization was continued for another $72 \mathrm{~h}$ at $42^{\circ} \mathrm{C}$. Blots were dried and autoradiographed with hybridization signals quantified as above. Exposures were within the linear range of the film.

In situ hybridizations. SJL mice were immunized with renal tubular antigen (RTA)/CFA to produce anti-tubular basement membrane disease (13). Control mice were immunized with CFA alone. Kidney sections of $5 \mu \mathrm{m}$ were cut from paraffin blocks after fixation in ethanol formaldehyde, and then applied to chromalum-treated slides (15). Sections were deparaffinized in $100 \%$ xylene, incubated in $1 \%$ Triton $\mathrm{X}-100$ for $10 \mathrm{~min}$ at $22^{\circ} \mathrm{C}$, and permeabilized in $10 \mathrm{mg} / \mathrm{ml}$ of proteinase $\mathrm{K}$ in $20 \mathrm{mM}$ Tris, $2 \mathrm{mM} \mathrm{CaCl}$, (pH 7.4) for $20 \mathrm{~min}$ at $37^{\circ} \mathrm{C}$. Hybridization fluid containing $50 \%$ formamide, $5 \times$ Denhardt's solution, $5 \times$ SSC, $10 \%$ dextran sulfate, $500 \mu \mathrm{g} / \mathrm{ml}$ ssDNA, $0.1 \%$ Triton $\mathrm{X}-100$, and $0.5 \mu \mathrm{g} / \mathrm{ml}$ of ${ }^{35} \mathrm{~S}$-labelled cDNA probe $\left(0.5-1.0 \times 10^{8} \mathrm{cpm} /\right.$ $\mu \mathrm{g}$ ) was heated to $100^{\circ} \mathrm{C}$ for $2 \mathrm{~min}$, iced, and admixed with DTT to final concentration of $10 \mathrm{mM}$. An aliquot of $40 \mu \mathrm{l}$ of fluid was applied to each slide, enclosed with a glass cover slip, and hybridized at $40^{\circ} \mathrm{C}$ for 4 to $18 \mathrm{~h}$. Sections were then washed $30 \mathrm{~min}$ with $2 \times \mathrm{SSC}$ at $22^{\circ} \mathrm{C}$, 30 min each with $0.1 \times \mathrm{SSC}$ and $0.1 \times \mathrm{SSC}$ at $65^{\circ} \mathrm{C}$, and $15 \mathrm{~min} 0.1 \times$ $\mathrm{SSC}$ at $37^{\circ} \mathrm{C}$. Slides were dipped in Kodak NTB-2, exposed for 2-5 d at room temperature, and the reaction product was developed with D19 and Kodak fixer. Slides were then counterstained with hematoxylin and examined under the microscope. Silver grains were counted in tubular cells expressing visible brush border from 10 random high power fields $(\times 800)$ on slides hybridized with ${ }^{35} \mathrm{~S}$-labelled types I and IV collagen probes. Grain counts from slides hybridized with pBR322 were subtracted as background, and the corrected counts were then expressed as a mean \pm SEM. All controls were run simultaneously.

Immunofluorescence. Portions of renal tissue were sectioned, placed on a cellulose sponge, and snap frozen in isopentane prechilled in liquid nitrogen and stored at $-70^{\circ} \mathrm{C}$. Cryostat sections, $4 \mu \mathrm{m}$ in thickness, were stained with conjugated antisera and evaluated in a Zeiss Universal microscope as described previously $(3,7,13,15)$. Optimal concentrations of FITC-conjugated affinity-purified mouse antirabbit IgG (Jackson Immunoresearch Laboratories, West Grove, PA) was used for indirect immunofluorescence to detect kidney tissue binding by primary monospecific rabbit antibodies to $\mathrm{M} 30-\mathrm{ThF}(6)$, and to types I and IV collagen (7). Normal rabbit sera were used as a control.

\section{Results}

In preparation for our initial experiments we purified antigenbinding $\mathrm{ThF}$ from a $\mathrm{CD}^{+}$helper $\mathrm{T}$ cell clone (M30) reactive with the 3M-1 renal tubular antigen expressed by cortical tubu- lar epithelium using a tubular antigen affinity column (6). This ThF resolved at $\sim 78,000 M_{\mathrm{r}}$ under reducing conditions on SDS-PAGE (Fig. 1), and was of predicted purity (6).

We next observed in Fig. $2 A$ that the addition of increasing concentrations of affinity-purified M30-ThF to cultures of MCT epithelium only increased slightly their incorporation of $\left[{ }^{3} \mathrm{H}\right] \mathrm{TdR}$, whereas the recombinant cytokine transforming growth factor $\beta$ (TGF $\beta$ ) predictably decreased the growth of MCT cells. The addition of M30-ThF also attenuated progressively their secretion of type IV collagen as measured at $72 \mathrm{~h}$ (Fig. $2 \mathrm{~B}$ ). In contrast, ThF did not alter greatly the secretion of type I collagen, except to raise it slightly at a mid-dose level (Fig. 2 C). To determine if the inhibition of secretion of type IV
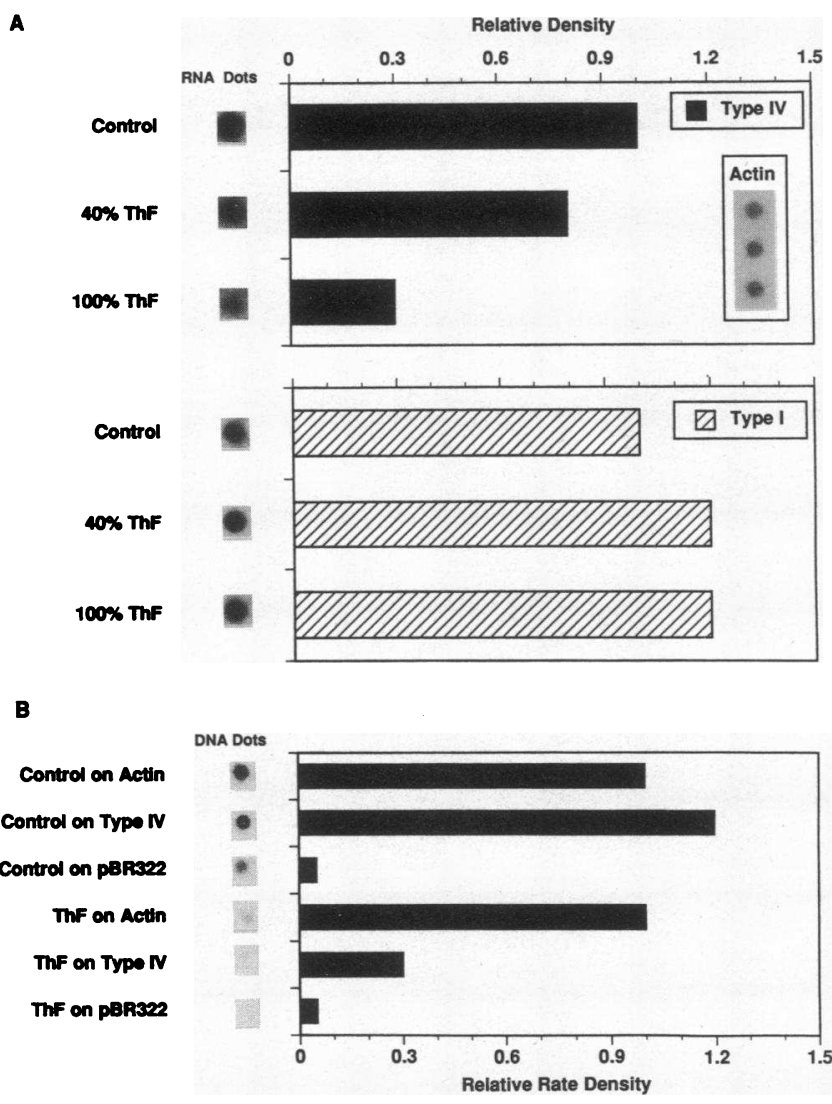

Figure 4. The effects of $\mathrm{ThF}$ on the transcriptional activity of collagen in MCT epithelium. (A) Cytoplasmic dot-blot hybridizations of MCT cell RNA with cDNA encoding types I and IV collagen following coculture with ThF. $10^{6} \mathrm{MCT}$ cells were cultured with $\mathrm{ThF}$ ( $40 \%$ and $100 \%$ equivalent concentrations) for $24 \mathrm{~h}$, after which $2 \times 10^{5}$ cell equivalents of cytoplasmic RNA were spotted onto Nytran and hybridized with ${ }^{32} \mathrm{P}$-labelled cDNA probes for types I and IV collagen (15). The results show a reduction in hybridizing transcripts for type IV collagen with a minimal increase in type I collagen between treated groups. A ${ }^{32} \mathrm{P}$-labelled cDNA probe encoding actin did not reveal differences in RNA loading (inset box in type IV bar graph); (B) Nuclear run-off transcription assay for type IV collagen. $10^{7} \mathrm{MCT}$ cells were cultured in serum free media with or without $\mathrm{ThF}$ at $100 \%$ equivalence for $48 \mathrm{~h}$. The transcription of their isolated nuclei was completed in the presence of $\left[{ }^{32} \mathrm{P}\right]$ UTP and hybridized to DNA specific for type IV collagen, actin, and pBR322 (15). The results indicate there is less transcription of type IV collagen in MCT cells treated with $\mathrm{ThF}$ when compared to controls. 

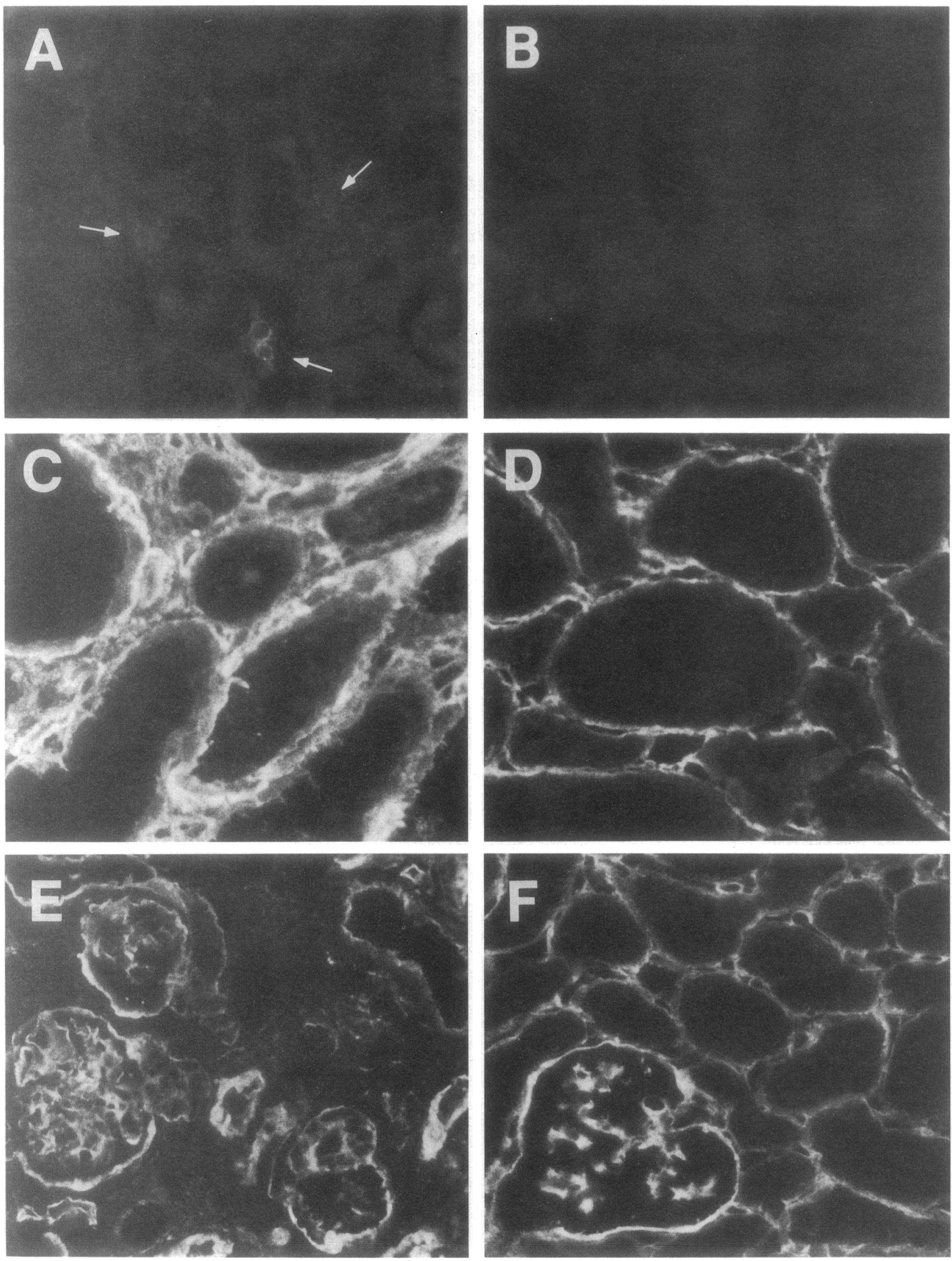

Figure 5. Immunofluorescent staining of kidney tissue expressing anti-tubular basement membrane disease and interstitial nephritis. $(A)$ 5-wk early nephritic kidneys stained with monospecific rabbit anti-ThF antibody plus FITC-mouse anti-rabbit IgG (6) identifies occasional mononuclear cells (arrows) located in the interstitium between tubules ( $\times 160) ;(B)$ FITC-mouse anti-rabbit IgG plus control rabbit antibody does not 
collagen by M30-ThF had immunologic specificity, we next examined the effects of other ThFs from $\mathrm{CD}^{+}$helper cells (M12) reactive to purified protein derivative $(5,9)$ as well as the impact of the recombinant cytokines TGF $\beta$ and epidermal growth factor (EGF). In Fig. $2 D, \mathrm{M} 12-\mathrm{ThF}, \mathrm{TGF} \beta$, and EGF all produced slight to substantial increases in the secretion of type IV collagen when cocultured in the presence of MCT cells, but did not yield the inhibitory effects observed with 3M-1-binding ThF obtained from M30 cells.

To examine the level at which ThF might have exerted its influence on the secretion of epithelial collagen, we compared the relative abundance of $\mathrm{mRNA}$ transcripts in MCT cells stimulated with 3M-1-binding ThF. First, in Fig. 3, we established that our labelled cDNA probes hybridized to appropriately sized mRNA harvested from MCT cells ( $\alpha$ 1[IV] mRNA: $\sim 6.5$ $\mathrm{kb}$, and $\alpha 2[\mathrm{I}]$ mRNA: $\sim 4.8$ and $5.8 \mathrm{~kb} ; 19)$. We next determined the relative change in $\alpha$ (IV) and $\alpha 2$ (I) mRNA collagen transcripts in MCT cells using RNA dot-blot hybridizations (15). Our findings in Fig. $4 A$ demonstrate that ThF raised slightly the transcript levels for type I collagen, whereas transcript levels for type IV collagen fell substantially. To determine whether this latter effect of ThF on $\alpha$ l(IV) transcripts was due to a change in the rate of transcription, we performed in vitro nuclear run-off experiments on nuclei isolated from MCT cells cocultured with ThF. In Fig. $4 B$, while ThF did not produce much change in the rate of transcription of actin, there was a substantial reduction in rate of transcription for type IV collagen.

To further extend our in vitro findings regarding changes in copy numbers of collagen transcripts, we next performed immunohistochemistry and in situ hybridizations on kidney sections obtained from mice immunized to produce anti-tubular basement membrane disease and interstitial nephritis (15). 3M-1-specific helper $\mathrm{T}$ cells producing $\mathrm{ThF}$ are present in such lesions $(5,6)$. Immunofluorescent examination of kidneys harvested 5 wk after immunization with RTA/CFA, at an early stage just before major damage begins to destroy the interstitial architecture (13), revealed in Fig. 5, $A$ and $B$, the presence of ThF-expressing mononuclear cells in the tubulointerstitium of nephritic mice. ThF-expressing mononuclear cells were not found in control kidneys immunized with CFA alone. In situ hybridizations, depicted in Fig. $6(A-D)$, were also performed by overlaying 5-wk nephritic kidney sections with ${ }^{35} \mathrm{~S}$-labelled cDNA encoding types I or IV collagen. Our findings indicate that the numbers of type IV collagen transcripts in cortical tubular cells were reduced to $10.2 \pm 2.2$ grains/high power field (hpf) (Fig. $6 \mathrm{D}$ ) in tubules involved in interstitial infiltrates when compared with control kidneys expressing $48.0 \pm 3.8$ grains/hpf (Fig. 6 B) $; P<0.01$. The transcript reaction product for type I collagen was increased from $3.5 \pm 0.9$ grains/hpf (Fig. $6 \mathrm{~A}$ ) in controls to $15.5 \pm 1.1$ grains/hpf in kidneys from mice with early disease (Fig. $6 C$ ); $P<0.01$. These changes in mRNA were confirmed in more advanced lesions by immunofluores- cent staining. Kidneys harvested 12 weeks after immunization demonstrated an increased staining for collagen type $I$ in the interstitium and perivascular areas (Fig. 5, $C$ and $D$ ) and a decreased staining for collagen type IV as evidenced by a reduced fraction of cortical tubules that were ringed by basement membrane (Fig. 5, $E$ and $F$ ).

\section{Discussion}

The antigen-binding ThF of anti-tubular basement membrane disease is secreted by $\mathrm{CD}^{+}$helper T cells (6), and these helper cells can be harvested from interstitial lesions (5). In the present experiments we were able to detect additionally the presence of this $\mathrm{ThF}$ in mononuclear cells scattered within the tubulointerstitial space. Although we only tested the ThF effect on proximal tubular cells in vitro, the $3 \mathrm{M}-1$ target antigen is found all along the cortical nephron of mice (13), and these ThF proteins might likely interact with any $3 \mathrm{M}-1$ antigen-secreting tubular segment.

Our experiments indicate that the in vitro transcription and secretion of type IV collagen in target epithelium can be repressed specifically by antigen-binding ThF. The effect of ThF on the secretion of type IV collagen was dose dependent, and the actions of EGF and TGF $\beta$ further demonstrate that type IV secretion can be modulated bi-directionally. Not a great deal of information exists currently regarding the effects of TGF $\beta$ and EGF on the secretion of type IV collagen in organ-derived epithelial cells. Under our culture conditions they appear to stimulate the secretion of type IV, a finding which might be predicted from work with TGF $\beta$ on type I collagen in fibroblasts (20), or with EGF on type IV secretion in myoepithelium (21). The unique effects of antigen-binding ThF that inhibit the secretion of type IV basement membrane collagen in its target epithelium was also not anticipated from previous work $(1,2)$. These novel findings nevertheless reinforce the notion that cytokinelike proteins may influence differentially the secretion of distinct phenotypes of collagen originating from the same cell.

We believe the mechanism of the effect of ThF on type IV secretion is likely related to a reduction in the rate of transcription of type IV in affected epithelium. The 20-fold decrease in the secretion of type IV collagen in MCT cells, however, is significantly greater than the observed 3-fold reduction in levels of $\alpha 1$ (IV) mRNA, suggesting that the repression of transcription of type IV collagen in MCT epithelium by ThF may represent only one of several potential mechanisms for the control of expression of collagen genes by paracrine regulatory proteins (22). The fall in type IV transcripts in MCT cells following the addition of $\mathrm{ThF}$ in vitro paralleled the reduction in type IV reaction product observed with the in situ hybridization of early nephritic kidneys. The increase in transcripts encoding type I collagen in vivo, however, is not what we observed in vitro with ThF. Since a variety of mononuclear cells are present in interstitial lesions (23), it is likely that other as yet

stain any cortical structures $(\times 160) ;(C)$ nephritic kidney sections harvested at 12 weeks after immunization with RTA/CFA (13) were stained with monospecific rabbit anti-type I collagen antibody (7) showing a marked increase in the deposition of type I collagen within the interstitial space and near thickened tubular basement membranes $(\times 400) ;(D)$ control kidney sections from mice immunized with CFA 12 weeks before harvest and stained with rabbit anti-type I collagen antibody $(\times 400) ;(E)$ nephritic kidney sections were harvested 12 weeks after immunization with RTA/CFA (13) and stained with monospecific rabbit anti-type IV collagen antibody (7) demonstrating a marked decrease in the numbers of cortical tubules resting on basement membrane containing type IV collagen $(\times 250) ;(F)$ control kidney sections from mice immunized with CFA 12 weeks before harvest and stained with rabbit anti-type IV collagen antibody to highlight normal tubules $(\times 250)$. 
Type I Procollagen
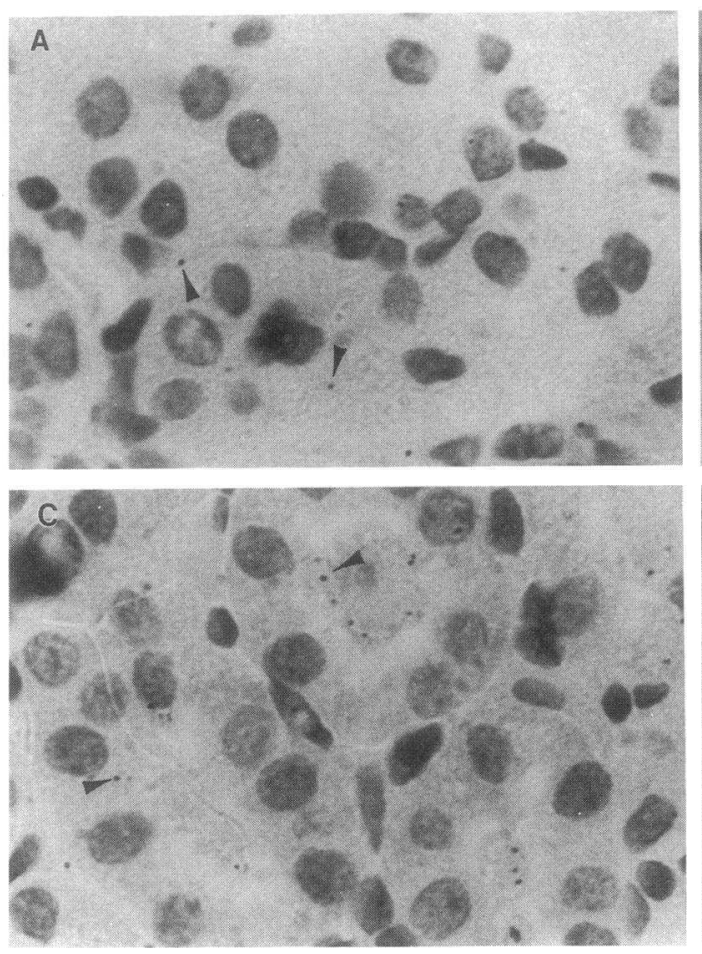

Type IV Procollagen
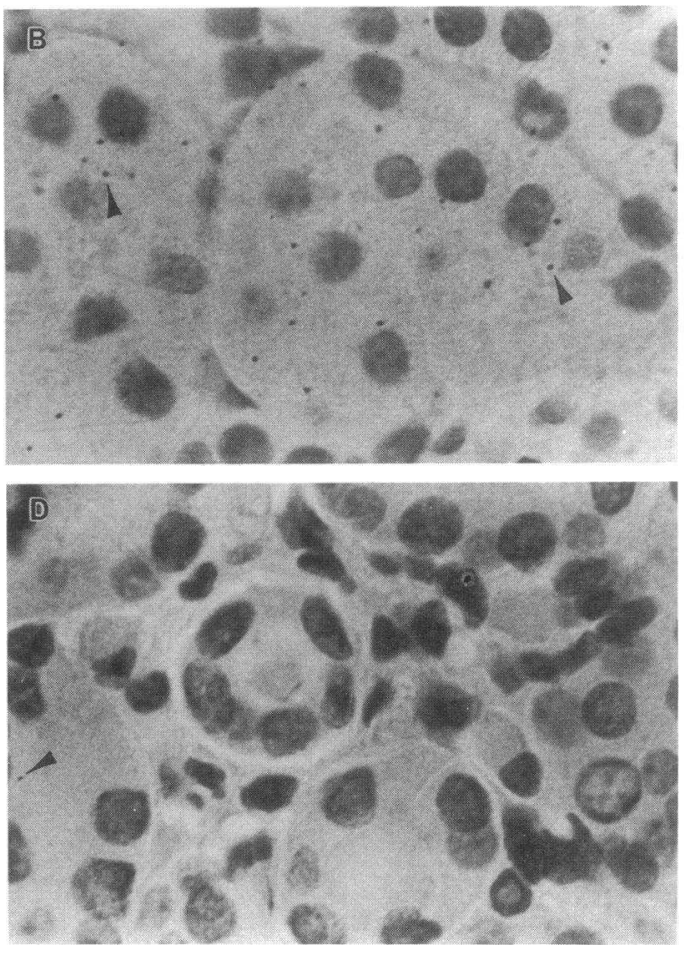

Control

$\alpha$ TBM Disease

Figure 6. In situ hybridization of kidney sections using ${ }^{35}$ S-labelled cDNA encoding types I and IV collagen (15). ( $A$ ) Control kidneys from SJL mice immunized with CFA and hybridized with cDNA probes for type I collagen. $(B)$ Control kidneys harvested from SJL mice immunized with CFA and hybridized with cDNA probes for type IV collagen. $(C)$ Kidneys harvested five weeks after the immunization of SJL mice with RTA/CFA to produce anti-tubular basement membrane disease (5) were hybridized with cDNA probes for type I collagen. (D) Kidneys harvested five weeks after the immunization of SJL mice with RTA/CFA to produce anti-tubular basement membrane disease were hybridized with cDNA probes for type IV collagen. These in situ results demonstrate a decrease in reaction product for type IV collagen and an increase in reaction product for type I collagen among cortical tubules involved with early interstitial infiltrates.

unidentified cytokines expressed concomitantly in this interstitial microenvironment may both increase type I secretion and/ or produce the same effects on type IV as ThF.

Cortical tubular epithelium and its associated basement membrane structures begin to wither with extended renal inflammation $(24,25)$. Our demonstration that disease-relevant antigen-binding $T$ cell proteins can modulate selectively the transcription and secretion of collagens in epithelium expressing appropriate target antigens provides additional new information regarding the process of parenchymal cell modification by autoimmune signalling events (15). A pathophysiologic bridge between renal tubular atrophy and the specific action of an antigen-binding protein has not been proposed before. The $3 \mathrm{M}-1$ antigen is a complex structure expressed as multiple isoforms (4). Its framework domain contains nephritogenic epitopes and has some structural similarity to intermediate filament-associated proteins. How ThF interactions with the $3 \mathrm{M}-1$ ligand might influence the biology of type IV collagen is currently under further investigation. The demonstration, nevertheless, of a direct effect of immune-somatic cell interactions on local organ remodelling lends support to the notion that some immune events may mediate progressive tubular atrophy. In our example the argument favors an architectural regression of otherwise mature renal parenchymal structures.

\section{Acknowledgments}

We thank Dr. Nicholas Kefalides, Director, Connective Tissue Research Institute, University of Pennsylvania, and Dr. Thomas Ka- desch, Howard Hughes Medical Institute, University of Pennsylvania, for helpful discussions of this manuscript.

This work was supported in part by grants AR-20553, DK-07006, DK-30280, DK-33501, DK-42155, and DK-41110 from the National Institutes of Health. E. G. Neilson is the recipient of an Established Investigator Award (85-108) from the American Heart Association and its Pennsylvania Affiliate. C. J. Kelly is the recipient of a Markey Scholar Award (86-019) from the Lucille P. Markey Charitable Trust. T. P. Haverty was supported by the Measey Foundation.

\section{References}

1. Neilson, E. G., S. A. Jimenez, and S. M. Phillips. 1980. Cell mediated immunity in interstitial nephritis. III. T lymphocyte mediated fibroblast proliferation and collagen synthesis: an immune mechanism for renal fibrogenesis. $J$. Immunol. 125:1708-1714.

2. Neilson, E. G., S. A. Jimenez, and S. M. Phillips. 1982. Lymphokine modulation of fibroblast proliferation. J. Immunol. 128:1484-1486.

3. Clayman, M. D., A. Martinez-Hernandez, L. Michaud, R. Alper, R. Mann, N. A. Kefalides, and E. G. Neilson. 1985. Isolation and characterization of the nephritogenic antigen producing anti-tubular basement membrane disease. $J$. Exp. Med. 161:290-305.

4. Neilson, E. G., M. J. Sun, C. J. Kelly, M. D. Clayman, and N. E. Cooke. 1991. Molecular characterization of a major nephritogenic domain in the autoantigen of anti-tubular basement membrane disease. Proc. Natl. Acad. Sci. USA. 88:2006-2010

5. Mann, R., B. Zakheim, M. D. Clayman, E. McCafferty, L. Michaud, and E. G. Neilson. 1985. Murine interstitial nephritis. IV. Long-term cultured L3T4+ $T$ cell lines transfer delayed expression of a disease as I-A restricted inducers of the effector T cell repertoire. J. Immunol. 135:286-293.

6. Hines, W. H., R. A. Mann, C. J. Kelly, and E. G. Neilson. 1990. Biochemical and functional characterization of an antigen-specific helper $T$ cell factor which induces the effector $T$ cell repertoire in autoimmune interstitial nephritis. J. Immunol. 144:75-83.

7. Haverty, T. P., C. J. Kelly, W. H. Hines, P. S. Amenta, M. Watanabe, N. A. 
Kefalides, R. Harper, and E. G. Neilson. 1988. Characterization of a renal tubular epithelial cell line which secretes the autologous target antigen of autoimmune interstitial nephritis. J. Cell Biol. 107:1358-1369.

8. Hines, W. H., T. P. Haverty, J. A. Elias, E. G. Neilson, and C. J. Kelly. 1989. T cell recognition of epithelial self. Autoimmunity. 5:37-47.

9. Mann, R., C. J. Kelly, M. Clayman, W. H. Hines, M. J. Sun, N. Blanchard, and E. G. Neilson. 1987. Effector T cell differentiation in experimental interstitial nephritis. I. Requirements for precursor cell development and effector lymphocyte maturation. J. Immunol. 138:4200-4208.

10. Karkavelas, G., N. A. Kefalides, P. S. Armenta, and A. Martinez-Hernandez. 1988. Comparative ultrastructural localization of collagens types III, IV, VI and laminin in rat uterus and kidney. J. Ultrastruct. Mol. Struct. Res. 100:137155.

11. Timpl, R., and M. Dziadek. 1986. Structure, development, and molecular pathology of basement membranes. Int. Rev. Exp. Pathol. 29:1-112.

12. Ekblom, P. 1989. Developmentally regulated conversion of mesenchyme to epithelium. FASEB (Fed. Am. Soc. Exp. Biol.) J. 3:2141-2150.

13. Neilson, E. G., and S. M. Phillips. 1982. Murine interstitial nephritis. I. Analysis of disease susceptibility and its relationship to pleiomorphic gene products defining both immune response genes and a restrictive requirement for cytotoxic T cells at H-2K. J. Exp. Med. 155:1075-1085.

14. Clayman, M. D., M. J. Sun, L. Michaud, J. Brill-Dashoff, R. Riblet, and E. G. Neilson. 1988. Clonotypic heterogeneity in experimental interstitial nephritis: restricted specificity of the anti-tubular basement membrane B cell repertoire is associated with a disease modifying cross-reactive idiotype. J. Exp. Med. 167:1296-1313.

15. Haverty, T. P., M. Watanabe, E. G. Neilson, and C. J. Kelly. 1989. Protective modulation of class II MHC gene expression in tubular epithelium by target antigen-specific antibodies: cell-surface directed down-regulation of transcription can influence susceptibility to murine tubulointerstitial nephritis. J. Immunol. 143:1133-1147.
16. Liau, G., Y. Yamada, and B. de Crombrugghe. 1985. Coordinate regulation of the levels of type III and type I collagen mRNA in most but not all mouse fibroblasts. J. Biol. Chem. 260:531-536.

17. Wang, S. Y., and L. J. Gudas. 1983. Isolation of cDNA clones specific for collagen IV and laminin from mouse teratocarcinoma cells. Proc. Natl. Acad. Sci. USA. 80:5880-5884.

18. Alonso, S., A. Minty, Y. Bourlet, and M. Buckingham. 1986. Comparison of three actin-coding sequences in the mouse: evolutionary relationships between the actin genes of warm blooded vertebrates. J. Mol. Evol. 23:11-22.

19. Myers, J. C., J. M. Brinker, N. A. Kefalides, J. Rosenbloom, S. Wang, and L. Gudas. 1986. Discrimination among multiple AATAAA sequences correlates with interspecies conservation of select 3 ' untranslated nucleotides. Nucleic Acids Res. 14:4499-4515.

20. Appling, W. D., W. E. O'Brien, D. A. Johnston, and M. Duvic. 1989 Synergistic enhancement of type I and III collagen production in cultured fibroblasts by transforming growth factor beta. FEBS (Fed. Eur. Biochem. Soc.) Lett. 250:541-544.

21. Petersen, O. W., and B. van Deurs. 1988. Growth factor control of myoepithelial-cell differentiation in cultures of human mammary gland. Differentiation 33:197-215.

22. Vuorio, E., and B. de Crombrugghe. 1990. The family of collagen genes. Annu. Rev. Biochem. 59:837-872.

23. Zakheim, B., E. McCafferty, S. M. Phillips, M. Clayman, and E. G. Neilson. 1984. Murine interstitial nephritis. II. The adoptive transfer of disease with immune $\mathrm{T}$ lymphocytes produces a phenotypically complex lesion. J. Immunol. 133:234-239.

24. Haverty, T. P., E. G. Neilson, and J. Kuncio. 1991. Mechanisms of tubulointerstitial fibrosis. Kidney Int. 39:550-556.

25. Heptinstall, R. H. 1968. Pathology of end-stage kidney disease. Am. J. Med. 44:656-662. 